\title{
Pengaruh Suhu Karbonisasi terhadap Kualitas Briket dari Tongkol Jagung dengan Limbah Plastik Polietilen Terephtalat sebagai Bahan Pengikat
}

\author{
The Effect of Carbonization Temperature on the Quality of Corncob Briquettes with Polyethylene \\ Terephthalate Plastic Waste as a Binder
}

\author{
Haryono*, Iman Rahayu, Yusi Deawati \\ Departemen Kimia, Fakultas Matematika dan Ilmu Pengetahuan Alam, Universitas Padjadjaran, JI. Raya Bandung- \\ Sumedang Km. 21, Jatinangor, 45363, Indonesia \\ *E-mail: haryono@unpad.ac.id
}

Diterima: 20 September 2020; Disetujui: 7 Desember 2020

\begin{abstract}
ABSTRAK
Jagung sebagai salah satu komoditas tanaman pangan memiliki peranan strategis. Biji jagung dapat dimanfaatkan untuk berbagai keperluan, seperti: bahan pangan alternatif pengganti beras, bahan baku utama pada pembuatan pakan ternak, dan bahan baku di industri pangan. Pada pemanfaatan jagung tersebut, mulai dari tahap pemanenan sampai perontokan biji jagung, dihasilkan sejumlah limbah. Sekitar 17,24\% dari limbah tersebut adalah limbah berupa tongkol jagung. Relatif tingginya kadar selulosa, hemiselulosa, dan lignin membuat tongkol jagung merupakan limbah biomassa potensial sebagai bahan baku bahan bakar bio, salah satunya adalah briket. Salah satu tahap proses pembuatan briket yang sangat menentukan kualitas briket adalah tahap karbonisasi biomassa. Tujuan penelitian ini adalah mempelajari pengaruh suhu karbonisasi tongkol jagung, terhadap penampilan fisik dan kualitas briket, dengan memanfaatkan limbah plastik PET sebagai bahan pengikat pembantu. Suhu karbonisasi dipelajari pada suhu 350,400 , dan $450{ }^{\circ} \mathrm{C}$. Sedangkan kualitas briket ditentukan berdasarkan parameter kualitas menurut SNI 01-6235-2000 tentang Briket Arang Kayu meliputi nilai kalor, kadar air, kadar abu, dan kadar volatile matter, serta komposisi gas buang pembakaran briket tersebut. Hasil penelitian menunjukkan bahwa briket yang dihasilkan dari tahap karbonisasi pada suhu $450{ }^{\circ} \mathrm{C}$ merupakan briket dengan kualitas paling optimum. Briket tongkol jagung pada suhu karbonisasi tersebut telah memenuhi standard kualitas menurut SNI 01$6235-2000$ dengan nilai kalor sebesar $6072,01 \mathrm{kal} / \mathrm{g}(25,38 \mathrm{MJ} / \mathrm{kg})$. Kadar air, abu, dan volatile matter dari briket tersebut berturut-turut sebesar 4,98,6,00, dan 7,00\%. Sedangkan berdasarkan uji komposisi gas buang, pembakaran briket tersebut menghasilkan gas hidrokarbon dengan kadar paling sedikit.
\end{abstract}

Kata kunci: briket; suhu karbonisasi; tongkol jagung; uji kualitas

\begin{abstract}
Corn as a food crop commodity has a strategic role. Corn kernels can be used for various purposes, such as: alternative food ingredients to substitute for rice, the main raw material for making animal feed, and raw materials in the food industry. In utilizing this corn, from the harvesting stage to the threshing of the corn kernels, a number of wastes are generated. About $17.24 \%$ of the waste is waste in the form of corn cobs. The relatively high levels of cellulose, hemicellulose, and lignin make corn cobs a potential biomass waste as raw material for bio-fuel, one of which is briquettes. One of the stages of the briquette-making process that really determines the quality of the briquettes is the biomass carbonization stage. The purpose of this study was to study the effect of corncob carbonization temperature on the physical appearance and quality of the briquettes by utilizing PET plastic waste as a supporting binding agent. The carbonization temperature was studied at 350,400 , and $450^{\circ} \mathrm{C}$. While the quality of the briquettes is determined based on the quality parameters according to SNI 01 6235-2000 concerning Wood Charcoal Briquettes, including the calorific value, moisture content, ash content and volatile matter content, as well as the composition of the combustion exhaust gas of the briquettes. The results showed that the briquettes produced from the carbonization stage at $450^{\circ} \mathrm{C}$ were the briquettes with the optimum quality. Corn cobs briquettes at the carbonization temperature have met the quality standards according to SNI 01-6235-2000 with a calorific value of $6072.01 \mathrm{cal} . / \mathrm{g}$ or $25.38 \mathrm{MJ} / \mathrm{kg}$. The moisture, ash, and volatile matter content of the briquettes were 4.98, 6.00, and $7.00 \%$, respectively. Meanwhile, based on the exhaust gas composition test, the combustion of the briquettes produces hydrocarbon gas with the least amount.
\end{abstract}

Keywords: briquette; carbonization temperature; corncob; quality test

\section{PENDAHULUAN}

Jagung merupakan salah satu jenis komoditas tanaman pangan strategis di Indonesia. Selain sebagai bahan pangan pengganti beras, jagung juga dimanfaatkan sebagai bahan baku pakan ternak dan bahan baku pada pembuatan tepung maizena, minyak jagung, pemanis, dan furfural (Kementerian Pertanian, 2016). Produksi jagung tingkat nasional cenderung mengalami peningkatan. Berdasarkan publikasi terakhir Biro Pusat Statistik, produksi jagung pipilan kering tingkat nasional pada tahun 2015 sekitar 19,6 juta ton, dengan provinsi Jawa Barat berkontribusi sekitar 959,9 ribu ton (Biro Pusat Statistik, 2020). Sedangkan produksi jagung nasional pada tahun 2016 sebesar 23,6 juta ton. Nilai tersebut meningkat menjadi 28,9 juta ton 
pada tahun 2017 dan 30 juta ton pada tahun 2018 (Kementerian Pertanian, 2019).

Nilai produksi jagung yang relatif tinggi di Indonesia tersebut, pada tahap pemanfaatannya, berdampak pada melimpahnya tongkol jagung yang dihasilkan. Pada proses pemanenan jagung dihasilkan sejumlah limbah. Dari limbah tersebut umumnya terdapat tongkol jagung sekitar 17,24\% (Yaning Zhang, A.E. Ghaly, \& Bingxi Li, 2012), dengan komposisi kimia basis kering terdiri dari $38,8 \%$ selulosa, $44,4 \%$ hemiselulosa, dan $11,9 \%$ lignin (Pointner, Kuttner, Obrlik, Jäger, \& Kahr, 2014). Keberadaan senyawasenyawa kimia tersebut pada tongkol jagung menjadikan tongkol jagung merupakan limbah biomassa potensial. Biomassa tongkol jagung merupakan bahan baku terbarukan untuk pembuatan berbagai produk kimia dan bahan bakar (biofuel). Salah satu jenis produk biofuel yang dapat dibuat dari tongkol jagung adalah bahan bakar briket.

Briket merupakan bahan bakar padat ramah lingkungan dan bersifat terbarukan sehingga pemanfaatannya sebagai bahan bakar dapat mengurangi dampak negatif penggunaan bahan bakar berbasis minyak bumi, batubara, dan gas alam. Briket dihasilkan dari teknologi pembriketan. Pembriketan diterapkan dengan maksud untuk memperbaiki sifat-sifat fisik dan nilai kalor limbah biomassa agar menjadi bahan baru dengan sifat-sifat lebih baik (kualitas lebih stabil, lebih tahan terhadap cuaca, dan waktu penyimpanan lebih lama), mudah ditangani, dan meningkat nilai kalornya (Ajiboye, Abdulkareem, \& Anibijuwon, 2017), (McDougal, Eidemiller, \& Weires, 2010). Beberapa jenis biomassa telah dipelajari sebagai bahan baku pembuatan briket, seperti serpihan sabut kelapa dan kulit padi (Islam, Hossain, \& Momin, 2014), debu batubara (Ajiboye et al., 2017), dan batang tanaman jagung (Xing, Fan, \& Jiang, 2018).

Pada proses pembuatan briket, jenis biomassa, kondisi (suhu dan waktu) karbonisasi, kondisi pembriketan (tekanan, jenis alat pembriket/penekan), dan bahan pengikat briket merupakan faktor-faktor yang harus diperhatikan (BTG Biomass Technology Group BV, 2013). Biomassa akan terdekomposisi termal dalam kondisi tanpa oksigen selama proses karbonisasi. Pada dekomposisi termal tersebut, biomassa dapat bertransformasi menjadi bio-arang, bio-oil, dan produk-produk gas (Irfan et al., 2016). Xing et al. menyatakan bahwa suhu karbonisasi pada proses pembuatan briket dari batang tanaman jagung berpengaruh terhadap kadar karbon (C) total, nilai energi, dan rendemen dari briket yang dihasilkan (Xing et al., 2018). Sedangkan bahan pengikat pada tahap pembriketan sangat dibutuhkan jika biomassa sebagai bahan baku briket memiliki densitas curah, kadar lignin, kadar karbohidrat mampu larut dalam air, dan kadar protein rendah, karena bahan-bahan kimia tersebut mampu membentuk jembatan ikatan antar butiran-butiran arang (Kpalo, Zainuddin, Manaf, \& Roslan, 2020). Kanji, tanah liat, tar kayu, pitch, dan molases merupakan bahan umum bahan pengikat (BTG Biomass Technology Group BV, 2013). Selain bahan-bahan tersebut, polimer sintetik dalam bentuk limbah plastik memiliki syarat sebagai bahan pengikat melalui tahap pelelehan. Zakari el al. telah meneliti pengaruh penambahan bahan pengikat dari bahan polivinil khlroida atau PVC terhadap nilai kalor briket dari limbah pertanian (Zakari, Ismaila, Sadiq, \& Nasiru, 2013). Limbah plastik potensial lainnya sebagai bahan pengikat adalah plastik dari bahan PET (polyethylene terephthalate).

Tujuan penelitian ini adalah mempelajari pengaruh suhu karbonisasi sebagai tahap pembentukan material dasar briket, yaitu karbon dari tongkol jagung, terhadap penampilan fisik dan kualitas briket, dengan memanfaatkan limbah plastik PET sebagai bahan pengikat pembantu (cobinder). Kualitas briket ditentukan berdasarkan parameter kualitas menurut SNI 01-6235-2000 tentang Briket Arang Kayu meliputi nilai kalor, kadar air, kadar abu, dan kadar volatile matter (Badan Standardisasi Nasional, 2000), serta komposisi gas buang pembakaran briket tersebut.

\section{METODOLOGI}

Pembuatan dan pengujian kualitas briket dari biomassa tongkol jagung (varietas jagung hibida) pada penelitian ini dilakukan melalui 3 tahap utama, yaitu: tahap karbonisasi, pembriketan, dan pengujian kualitas briket (sifat fisika dan komposisi gas buang). Tongkol jagung sebagai limbah biomassa diperoleh dari beberapa pedagang jagung pipilan di pasar-pasar tradisional di Kota Bandung, Jawa Barat.

Pada tahap karbonisasi, makromolekul organik dari biomassa dikonversi menjadi arang (bio-char) sebagai produk utama. Tongkol jagung dipotong ke arah memanjang setebal sekitar 1,0 cm kemudian dicuci dengan air bersih. Potongan tongkol jagung dikeringkan dalam oven pada suhu $105^{\circ} \mathrm{C}$ selama 2 jam untuk mengurangi kadar air bebas. Selanjutnya potongan tongkol jagung kering dikarbonisasi dengan suhu divariasikan pada 350,400 , dan $450{ }^{\circ} \mathrm{C}$ selama masing-masing 30 menit di dalam muffle furnace (Thermoline ${ }^{\mathrm{TM}}, 100-1200^{\circ} \mathrm{C}$ ) dengan laju kenaikan suhu $10^{\circ} \mathrm{C} /$ menit. Arang tongkol jagung hasil karbonisasi didinginkan dalam desikator sampai suhu atmosferis. Arang kemudian diperkecil ukurannya dengan mortar, dan diayak dengan pengayak mekanik getar untuk diperoleh serbuk arang berukuran lolos 40 mesh $(0,42 \mathrm{~mm})$.

Tahap berikutnya adalah pembriketan. Bahan pengikat berupa plastik bekas jenis PET dicuci sampai bersih dan dikeringkan. Plastik PET selanjutnya dipotong dengan ukuran $0,5 \mathrm{~cm} \times 0,5 \mathrm{~cm}$. $100 \mathrm{~g}$ campuran arang tongkol jagung dan bahan pengikat PET disiapkan dengan variasi komposisi campuran arang dan PET pada rasio berat 95:5. Selanjutnya campuran arang dan PET tersebut dicampur lagi dengan air kanji sebagai bahan pengikat utama. Air kanji disiapkan dengan mencampurkan kanji dan air masing-masing sebanyak 7 dan 15\% terhadap berat campuran arang dan PET. Campuran arang tongkol jagung dan bahan pengikat dibriketkan dengan alat pembriket tipe hydraulic press. Pembriketan dilakukan pada tekanan 7 $\mathrm{MPa}$ yang diaplikasikan pada cetakan briket berdiameter $7,5 \mathrm{~cm}$. Briket hasil pengepresan selanjutnya dipanaskan dalam muffle furnace pada suhu $500^{\circ} \mathrm{C}$ selama 15 menit (Thermoline ${ }^{\mathrm{TM}}, 100-1200{ }^{\circ} \mathrm{C}$ ) dengan laju kenaikan suhu $10{ }^{\circ} \mathrm{C} /$ menit agar plastik PET sebagai co-binder dapat fungsi dengan optimal. Briket tongkol jagung yang dihasilkan dari variasi suhu karbonisasi pada suhu 350, 400 , dan $450^{\circ} \mathrm{C}$ berturut-turut diberi simbol B-350, B-400, dan B-450.

B-350, B-400, dan B-450 kemudian diuji kualitasnya berdasarkan parameter nilai kalor, kadar air, kadar abu, dan kadar volatile matter (SNI 01-6235-2000). Sedangkan evaluasi briket sebagai bahan bakar ramah lingkungan dipantau melalui hasil analisis jenis dan komposisi gas buang dari pembakaran masing-masing briket tersebut. Pada penentuan nilai kalor, nilai kalor dari briket dianalisis dengan kalorimeter bom IKA Model C 2000. Nilai kalor yang diperoleh merupakan HHV (high heating value) dari sampel briket. Kadar air, abu, dan volatile matter ditentukan dengan metode gravimetri. Hanatech Ultra 4/5 Gas Analyzer Model IM 2400 digunakan untuk menentukan jenis dan komposisi gas buang yang dihasilkan dari pembakaran sampel briket. 


\section{HASIL DAN PEMBAHASAN}

\section{Penampilan Fisik Briket}

Pembuatan briket dari tongkol jagung dengan variasi suhu karbonisasi $\left(350,400\right.$, dan $450^{\circ} \mathrm{C}$ ) dihasilkan briket dengan penampilan fisik beragam ditinjau dari paramter warna dan kekompakan. Perbandingan penampilan fisik briket dari ketiga variasi suhu karbonisasi tersebut ditampilkan pada Gambar 1.

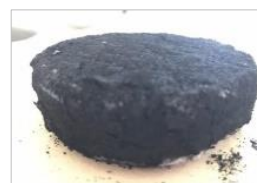

(B-350)

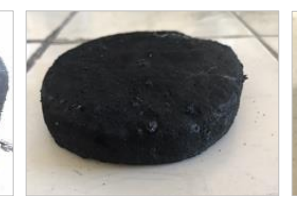

(B-400)

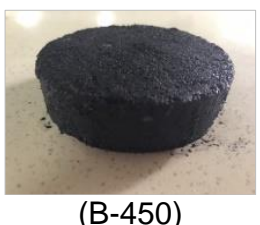

(B-450)
Gambar 1. Perbandingan penampilan fisik briket dari variasi suhu karbonisasi

Gambar 1 menunjukkan B-350 berwarna hitam dengan sedikit partikulat abu berwarna putih. Struktur briket tersebut cenderung lebih rapuh dan kurang kompak dibandingkan dengan kedua briket lainnya. Briket dengan penampilan fisik terbaik, yaitu berwarna hitam (dengan kontaminan partikulat abu minimal), berbentuk utuh (tidak rapuh), dan kompak ditunjukkan oleh B-450. Hasil tersebut menunjukkan bahwa tahap karbonisasi dengan suhu lebih tinggi akan dihasilkan briket dengan penampilan fisik dan sifat mekanik lebih baik. Peningkatan suhu karbonisasi terhadap biomassa sampai pada suhu $500{ }^{\circ} \mathrm{C}$ akan berdampak terhadap peningkatan volume pori dan luas permukaan spesifik (Irfan et al., 2016). Peningkatan volume pori spesifik briket ini akan menyebabkan probabilitas jumlah molekul bahan perekat (air kanji dan PET) masuk ke dalam pori-pori partikel briket semakin besar, sedangkan peningkatan luas permukaan spesifik dari briket akan berdampak semakin luasnya permukaan kontak antara partikel briket dengan bahan perekat. Kondisi ini mengakibatkan bahan pengikat akan berfungsi secara optimal sebagai perekat antar partikel-partikel penyusun briket pada saat tahap pengepresan.

Peningkatan suhu karbonisasi tersebut juga berdampak pada meningkatnya kadar $\mathrm{C}$ total, dan diiringi dengan pengurangan kadar hidrogen $(\mathrm{H})$ dan oksigen $(\mathrm{O})$ dari briket (Xing, Fan, \& Jiang, 2018; Irfan et al., 2016). Irfan et al. menemukan bahwa pengurangan rasio molar $\mathrm{O} / \mathrm{C}$ dan $\mathrm{H} / \mathrm{C}$ pada briket menyebabkan tingkat polaritas briket menurun atau lebih bersifat non polar (Irfan et al., 2016). Pada penelitian ini digunakan PET sebagai co-binder. PET bersifat hidrofob (non-polar), dan sifat adhesivitas serta kehidrofilikannya akan meningkat jika dimodifikasi dengan kanji (Wiacek, Jurak, Gozdecka, \& Worzakowska, 2017). Sehingga dengan semakin tingginya suhu karbonisasi, fungsi PET sebagai co-binder akan meningkat.

Peningkatan sifat mekanik dari briket dalam hal tingkat ketahanan mekanik dan kuat desak sebagai dampak semakin tingginya suhu karbonisasi juga dilaporkan oleh peneliti lain (Xing et al., 2018). Pada penelitian ini, sifat mekanik diwakili dari paramter fisik berupa tingkat kekompakan dan kerapuhan dari briket.

\section{Hasil Uji Kualitas Briket}

Pada penelitian ini, parameter kualitas briket yang uji meliputi nilai kalor, kadar air, kadar abu, dan kadar volatile matter. Untuk menentukan kelayakan kualitas dari sampel briket tongkol jagung, hasil uji setiap parameter kualitas tersebut dibandingkan dengan syarat kualitas briket menurut SNI 01-6235-2000 tentang Kualitas Briket Arang
Kayu. Gambar 2 menampilkan hasil uji nilai kalor dan perbandingannya dengan nilai kalor briket menurut SNI.

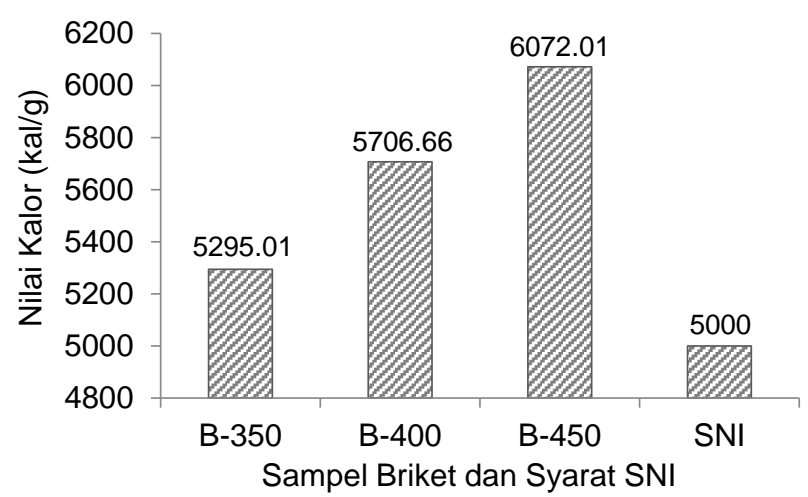

Gambar 2. Nilai kalor briket tongkol jagung pada berbagai variasi suhu karbonisasi dan perbandingannya dengan SNI (nilai kalor briket menurut SNI 01 $6235-2000=\min .5000 \mathrm{kal} / \mathrm{g}$ )

SNI tentang Briket Arang Kayu mensyaratkan nilai kalor minimal dari briket sebesar $5000 \mathrm{kal} / \mathrm{g}$. Seperti ditampilkan pada Gambar 2, ketiga sampel briket (B-350, B-400, dan B-450) dari berbagai variasi suhu karbonisasi memiliki nilai kalor melebihi ketentuan SNI 01-6235-2000. Nilai kalor briket mengalami peningkatan dari 5295,01 kal/g (22,13 $\mathrm{MJ} / \mathrm{kg})$ sampai $6072,01 \mathrm{kal} / \mathrm{g}(25,38 \mathrm{MJ} / \mathrm{kg})$ seiring dengan kenaikan suhu karbonisasi dari 350 sampai $450{ }^{\circ} \mathrm{C}$. Kecenderungan tersebut sesuai dengan hasil penelitian tentang pembuatan briket dari batang tanaman jagung. Nilai kalor briket meningkat dari 21,86 sampai $24,55 \mathrm{MJ} / \mathrm{kg}$ ketika suhu karbonisasi divariasikan pada rentang 400$600{ }^{\circ} \mathrm{C}$ (Xing et al., 2018). Sedangkan pada pembuatan briket dari campuran limbah biji kopi dan kertas, dari tahap karbonisasi pada suhu $260^{\circ} \mathrm{C}$ dihasilkan briket dengan nilai kalor $21,32 \mathrm{MJ} / \mathrm{kg}$, dan nilai kalor briket meningkat menjadi 23,06 MJ/kg ketika suhu karbonisasi diubah menjadi $290^{\circ} \mathrm{C}$ (Nurshalina, 2014). Peningkatan nilai kalor briket seiring dengan kenaikan suhu karbonisasi tersebut disebabkan oleh meningkatnya kadar $\mathrm{C}$ total atau rasio molar $\mathrm{C}$ terhadap $\mathrm{H}$ dan $\mathrm{O}$. $\mathrm{Hal}$ tersebut terbukti, jika dibandingkan dengan biomassa awal dimana rasio molar $\mathrm{C} / \mathrm{H}$ dan $\mathrm{C} / \mathrm{O}-$ nya rendah (sebagai akibat atom $\mathrm{H}$ dan $\mathrm{O}$ masih terikat pada struktur molekul biomassa), nilai energi biomassa tersebut lebih rendah daripada nilai kalor dalam bentuk briket. Biomassa tongkol jagung dilaporkan memiliki nilai kalor sebesar 16,13 MJ/kg (Kpalo et al., 2020). Nilai kalor briket tongkol jagung dari penelitian ini berkisar pada $22,13-25,38 \mathrm{MJ} / \mathrm{kg}$. Nilai kalor tersebut setara dengan nilai kalor batubara jenis bituminous yang memiliki nilai kalor 18,8-29,3 MJ/kg. Peningkatan suhu karbonisasi secara teknis, sesuai dengan hasil penelitian, memang akan meningkatkan nilai kalor dari briket yang dihasilkan sebagai dampak peningkatan kadar karbon dalam briket. Namun demikian, peningkatan kadar karbon yang dihasilkan dari dekomposisi terbal senyawa organik dari biomassa tersebut akan mengurangi yield massa briket. Penurunan yield massa briket ini berkonsekuensi terhadap penurunan yield energi briket yang dihasilkan (Xing et al., 2018). Yield massa briket didefinisikan sebagai perbandingan massa antara briket yang dihasilkan terhadap bahan baku biomassa. Sedangkan yield energi briket merupakan perbandingan antara nilai kalor briket terhadap nilai kalor bahan baku biomassa, dikalikan dengan yield massa briket. Selain itu, secara ekonomis, pelaksanaan karbonisasi dengan suhu semakin tinggi (kebutuhan energi meningkat) menyebabkan proses menjadi lebih tidak ekonomis. Oleh karena itu, terkait pemilihan suhu karbonisasi ini, harus 
dilakukan optimasi dengan mempertimbangkan aspek teknis dan ekonomis.

Parameter uji kualitas briket lainnya adalah kadar air, abu, dan volatile matter. Kadar air di dalam briket mempengaruhi usaha penyalaan awal briket. Sedangkan abu merupakan campuran berbagai oksida logam. Keberadaan air dan abu di dalam briket akan berdampak terhadap penurunan nilai kalor briket. Hal tersebut sebagai akibat sebagian panas yang dihasilkan pada pembakaran briket diserap oleh air untuk proses evaporasi dan abu untuk peningkatan suhunya. Volatile matter adalah bagian dari bahan bakar yang dilepaskan dalam bentuk gas atau uap berupa hidrokarbon atau gas lain sebagai hasil dekomposisi residu pada pemanasan terkontrol (Vyas, Sayyad, Khardiwar, \& Kumar, 2015). Sehingga keberadaan volatile matter di dalam briket mewakili pengotor berupa bahan-bahan organik yang tidak berhasil terkonversi menjadi karbon atau arang selama proses karbonisasi. Kadar volatile matter di dalam bahan bakar padat berhubungan dengan karakteristik pembakaran. Bahan bakar dengan kadar volatile matter tinggi cenderung memiliki nilai kalor lebih rendah (Pallavi, Srikantaswamy, Kiran, Vyshnavi, \& Ashwin, 2013) dan menimbulkan lebih banyak asap ketika dibakar (Nurshalina, 2014). Tabel 1 menampilkan hasil uji ketiga parameter kualitas dari masing-masing briket.

Tabel 1. Hasil uji kadar air, abu, dan volatile matter dari briket tongkol jagung pada variasi suhu karbonisasi dan perbandingannya dengan SNI

\begin{tabular}{cccc}
\hline \multirow{2}{*}{ Jenis briket } & \multicolumn{3}{c}{ Parameter uji } \\
\cline { 2 - 4 } & $\begin{array}{c}\text { Kadar air } \\
(\%)\end{array}$ & $\begin{array}{c}\text { Kadar abu } \\
(\%)\end{array}$ & $\begin{array}{c}\text { Volatile } \\
\text { Matter (\%) }\end{array}$ \\
\hline B-350 & 6,08 & 7,00 & 8,0 \\
B-400 & 5,88 & 6,36 & 8,0 \\
B-450 & 4,98 & 6,00 & 7,0 \\
SNI & Maks. 8,0 & Maks. 8,0 & Maks. 18 \\
\hline
\end{tabular}

Tabel 1 menunjukkan bahwa kualitas briket dari semua variasi suhu karbonisasi telah memenuhi standar kualitas arang briket menurut SNI 01-6235-2000. Namun kualitas briket masih akan dikonfirmasikan dengan hasil uji jenis dan komposisi gas buang dari pembakaran ketiga briket tersebut.

Kadar abu dan volatile matter dalam briket sangat dipengaruhi oleh jenis biomassa yang digunakan sebagai bahan baku sumber karbon (Vyas et al., 2015) dan komposisi dari biomassa-bahan perekat (Borowski \& Hycnar, 2013). Secara teori, jenis biomassa dan bahan perekat (terutama perekat dari bahan organik) memiliki kandungan abu dan volatile matter dengan kadar tertentu. Selama tahap karbonisasi, sejumlah tertentu berbagai jenis senyawa organik sederhana dan bersifat volatile akan meninggalkan fase padat pada sistem reaksi dalam wujud gas sebagai syngas, selain dihasilkan pula campuran senyawa organik berfase cair sebagai bio-oil (Irfan et al., 2016). Pada karbonisasi dengan suhu semakin tinggi, semakin banyak produk fase gas dan cair akan dihasilkan. Oleh karena itu potensi senyawa organik volatil sisa yang terkandung di dalam briket akan semakin sedikit. Dengan demikian kadar volatile matter pada briket akan menurun seiring dengan kenaikan suhu karbonisasi. Adanya sedikit penyimpangan pada kadar volaite matter terhadap suhu karbonisasi diduga sebagai dampak keberadaan PET sebagai bahan pengikat yang juga berkontibusi pada jenis dan kadar volatile matter ini.

Kecenderungan yang sama terjadi pada hubungan antara kadar air atau kelembaban briket dengan suhu karbonisasi. Selama tahap karbonisasi biomassa tersebut, air di dalam biomassa akan menguap dan meninggalkan biomassa. Suhu karbonisasi yang semakin tinggi akan mempercepat laju penguapan air meninggalkan biomassa. Sehingga dalam waktu karbonisasi tertentu, sisa air dalam arang hasil karbonisasi akan semakin sedikit ketika karbonisasi dilakukan pada suhu semakin tinggi.

\section{Analisis Komposisi Gas Buang Pembakaran Briket}

Analisis jenis dan komposisi gas buang dari briket dilakukan untuk mengetahui dampak lingkungan yang ditimbulkan dalam bentuk emisi gas-gas dengan sifat-sifat yang tidak diinginkan, seperti tingkat toksisitas, keasaman, dan isu pemanasan global. Hasil analisis tersebut ditampilkan pada Gambar 3 dan Tabel 2. Gambar 3 menampilkan print-out hasil analisis dari gas analyzer terhadap gas buang yang diemisikan dari pembakaran ketiga sampel briket tongkol jagung. Sedangkan Tabel 2 disajikan untuk mempermudah pembandingan jenis dan komposisi gas buang dari pembakaran ketiga sampel briket.

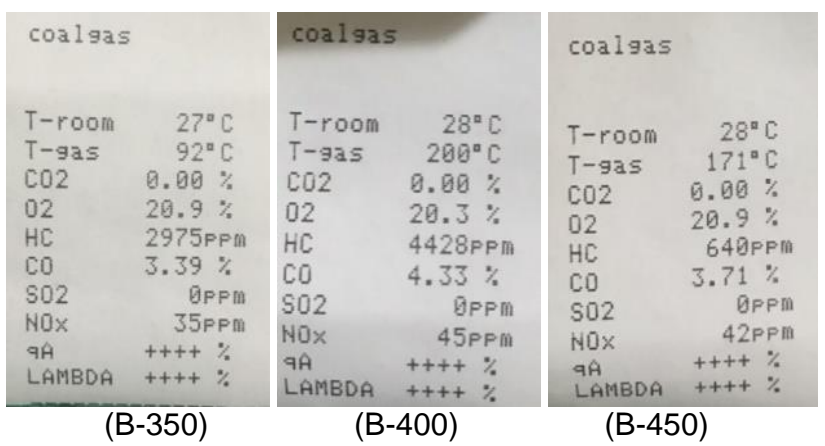

Gambar 3. Perbandingan jenis dan komposisi gas buang dari pembakaran briket yang dihasilkan dari berbagai variasi suhu karbonisasi

Tabel 2. Perbandingan jenis dan komposisi gas buang dari pembakaran briket tongkol jagung dari berbagai variasi suhu karbonisasi

\begin{tabular}{ccccc}
\hline \multirow{2}{*}{$\begin{array}{c}\text { Jenis } \\
\text { briket }\end{array}$} & \multicolumn{4}{c}{ Komposisi gas buang } \\
\cline { 2 - 5 } B-350 & $\mathrm{O}_{2}(\%)$ & $\mathrm{HC}(\mathrm{ppm})$ & $\mathrm{CO}(\%)$ & $\mathrm{NO}(\mathrm{ppm})$ \\
\hline B-400 & 20,9 & 2975 & 3,39 & 35 \\
B-450 & 20,3 & 4428 & 4,33 & 45 \\
\hline
\end{tabular}

Pada tahap uji emisi gas buang dari briket, gas karbon dioksida $\left(\mathrm{CO}_{2}\right)$ sebagai jenis gas buang yang timbul pada pembakaran sempurna, nampak pada Gambar 3, diatur sama dengan nol. Sedangkan keberadaan oksigen dalam gas buang menunjukkan oksigen sisa atau oksigen yang tidak bereaksi pada pembakaran briket dengan udara. Komponen gas buang hidrokarbon (HC) dijumpai dalam kadar paling sedikit pada pembakaran B-450. Hal tersebut mengindikasikan bahwa keberadaan senyawa organik sebagai pengotor, karena belum terkonversi menjadi arang pada tahap karbonisasi, di dalam briket B-450 paling sedikit. Hal ini selaras dengan kecenderungan pada hubungan antara suhu karbonisasi dengan nilai kalor briket dimana nilai kalor briket tersebut sebanding dengan tingkat konversi biomassa menjadi arang.

Kadar $\mathrm{CO}$ dan $\mathrm{NO}_{x}$ dalam gas buang dari pembakaran ketiga jenis briket, sesuai data pada Gambar 3 dan Tabel 2, menunjukkan ketidakkonsistenan. Kadar $\mathrm{CO}$ minimal dijumpai pada gas buang dari pembakaran briket B-350. Kandungan $\mathrm{CO}$ dengan kadar relatif sama (hanya terdapat perbedaan 0,32 ppm) terukur pada pengujian gas buang 
dari pembakaran briket B-450. Perbedaan kadar CO dalam gas buang dari pembakaran ketiga jenis briket diduga sebagai dampak efektifitas kontak antara struktur fisik briket dang udara. Efektifitas kontak antara bahan bakar dan udara selama reaksi pembakaran merupakan fenomena kompleks. Kadar $\mathrm{NO}_{x}$ dalam gas buang juga menunjukkan hubungan yang tidak konsisten. Pada pembakaran bahan bakar, $\mathrm{NO}_{\mathrm{x}}$ terbentuk dari reaksi oksidasi terhadap atom $\mathrm{N}$ yang terdapat pada struktur molekul bahan bakar oleh oksigen di dalam udara. $\mathrm{NO}_{x}$ akan terbentuk dalam kadar sangat rendah dari pembakaran pada suhu di bawah 760 ${ }^{\circ} \mathrm{C}$. Kadar $\mathrm{NO}_{x}$ dalam gas buang pembakaran akan meningkat seiring dengan semakin tingginya suhu pembakaran dan semakin rendahnya rasio mol bahan bakar terhadap oksigen (Environmental Protection Agency (EPA), 1999). Nampak pada Gambar 3, kadar NOx tertinggi terukur pada pembakaran briket B-400, yaitu 45 ppm, sebagai dampak pembakaran briket berlangsung pada suhu tertinggi $\left(200^{\circ} \mathrm{C}\right)$.

Berdasarkan atas pertimbangan penampilan fisik (sebagai perwakilan sifat mekanik), nilai kalor, dan komposisi gas buang pembakaran serta penjelasannya, briket tongkol jagung yang dihasilkan dari tahap karbonisasi pada suhu $450{ }^{\circ} \mathrm{C}$ ditetapkan sebagai briket tongkol jagung dengan kualitas paling optimum.

\section{KESIMPULAN}

Peningkatan suhu karbonisasi pada pembuatan briket dari dari tongkol jagung berdampak terhadap peningkatan nilai kalor dari briket yang dihasilkan. Selain itu, peningkatan suhu tahap karbonisasi tersebut menghasilkan briket dengan kadar air, abu, dan volatile matter semakin menurun secara relatif konsisten.

Pada pengujian komposisi gas buang, terjadi kecenderungan penurunan kadar $\mathrm{HC}$ secara konsisten pada gas buang yang diemisikan dari pembakaran briket tongkol jagung yang dihasilkan dari tahap karbonisasi dengan suhu semakin meningkat. Fluktuasi kadar $\mathrm{CO}$ dan $\mathrm{NO}_{x}$ pada hasil uji gas buang diduga sebagai akibat dari aspek ketidakstabilan kontak dan suhu pengujian.

Briket tongkol jagung yang dihasilkan dari semua variasi suhu karbonisasi telah memenuhi standard kualitas menurut SNI SNI 01-6235-2000 tentang Briket Arang Kayu, beradasarkan parameter nilai kalor, kadar air, kadar abu, dan kadar volatile matter.

\section{DAFTAR PUSTAKA}

Ajiboye, T., Abdulkareem, S., \& Anibijuwon, A. O. Y. (2017). Investigation of mechanical properties of briquette product of sawdust-charcoal as a potential domestic energy source. Journal of Applied Sciences and Environmental Management, 20(4), 1179. https://doi.org/10.4314/jasem.v20i4.34

Badan Standardisasi Nasional, B. A. K. (2000). Standar Nasional Indonesia Briket Arang Kayu. Sni, 1-4.

Biro Pusat Statistik. (2020). Retrieved from https://www.bps.go.id/publication/2020/02/28/6e654d d717552e82fb3c2ffe/statistik-indonesia--penyediaandata-untuk-perencanaan-pembangunan.html

Borowski, G., \& Hycnar, J. J. (2013). Utilization of fine coal waste as a fuel briquettes. International Journal of Coal Preparation and Utilization, 33(4), 194-204. https://doi.org/10.1080/19392699.2013.787993

BTG Biomass Technology Group BV. (2013). Charcoal production from alternative feedstocks. NL Agency, NL Energy and Climate Change, 1-77.
Environmental Protection Agency (EPA). (1999). Nitrogen oxides (NOx), why and how they are controlled. Epa456/F-99-006R, (November), 48. https://doi.org/EPA 456/F-99-006R

Irfan, M., Chen, Q., Yue, Y., Pang, R., Lin, Q., Zhao, X., \& Chen, H. (2016). Co-production of biochar, bio-oil and syngas from halophyte grass (Achnatherum splendens L.) under three different pyrolysis temperatures. Bioresource Technology, 211(March 2016), https://doi.org/10.1016/j.biortech.2016.03.077

457-463.

Islam, M. H., Hossain, M. M., \& Momin, M. A. (2014). Development of briquette from coir dust and rice husk blend: An alternative energy source. International Journal of Renewable Energy Development, 3(2), 119-123. https://doi.org/10.14710/ijred.3.2.119-123

Kementerian Pertanian. (2016). Outlook Jagung Komoditas Sub Sektor Tanaman Pangan, 85.

Kementerian Pertanian. (2019). Produksi dan Kualitas Jagung Indonesia Tidak Kalah Saing dengan Impor. Retrieved from https://www.pertanian.go.id/home/?show=news\&act= view\&id=3933

Kpalo, S. Y., Zainuddin, M. F., Manaf, L. A., \& Roslan, A. M. (2020). Production and characterization of hybrid briquettes from corncobs and oil palm trunk bark under a low pressure densification technique. $\begin{array}{ll}\text { Sustainability } & \text { (Switzerland), }\end{array}$ https://doi.org/10.3390/su12062468

McDougal, O., Eidemiller, S., \& Weires, N. (2010). Biomass Briquettes: Turning Waste Into Energy. Biomass Magazine, 1-3. Retrieved from http://biomassmagazine.com/articles/5148/biomassbriquettes-turning-waste-into-energy

Nurshalina, M. R. (2014). The production of briquette from coffee waste.

Pallavi, H., Srikantaswamy, S., Kiran, B., Vyshnavi, D., \& Ashwin, C. (2013). Briquetting agricultural waste as an energy source. Journal of Environmental Science, Computer Science and Engineering \& Technology, 2(1), 160-172.

Pointner, M., Kuttner, P., Obrlik, T., Jäger, A., \& Kahr, H. (2014). Composition of corncobs as a substrate for fermentation of biofuels. Agronomy Research, 12(2), 391-396.

Vyas, D., Sayyad, F., Khardiwar, M., \& Kumar, S. (2015). Physicochemical Properties of Briquettes from Different Feed Stock. Current World Environment, 10(1), 263-269. https://doi.org/10.12944/cwe.10.1.32

Wiacek, A. E., Jurak, M., Gozdecka, A., \& Worzakowska, M. (2017). Interfacial properties of PET and PET/ starch polymers developed by air plasma processing. Colloids and Surfaces A: Pysicochemical and Engineering Aspects, 532, 323-331. Retrieved from https://doi.org/10.1016/j.colsurfa.2017.04.074

Xing, X., Fan, F., \& Jiang, W. (2018). Characteristics of biochar pellets from corn straw under different pyrolysis temperatures. Royal Society Open Science, 5(8). https://doi.org/10.1098/rsos.172346

Yaning Zhang, A.E. Ghaly, \& Bingxi Li. (2012). Physical Properties of Corn Residues. American Journal of Biochemistry and Biotechnology, 8(2), 10. https://doi.org/10.3844/ajbb.2012.44.53

Zakari, I., Ismaila, A., Sadiq, U., \& Nasiru, R. (2013). Investigation on the Effects of Addition of Binder and Particle Size on the High Calorific Value of Solid Biofuel Briquettes, 3(12), 30-35. 
TEKNOTAN, Vol. 14, No. 2, Desember 2020

Halaman ini dikosongkan 